\title{
PELATIHAN MANAJEMEN WIRAUSAHA DAUR ULANG LIMBAH KAIN DI KAMPUNG LEUWIHALANG KELURAHAN SUKAMANAH KECAMATAN CIPEDES KOTA TASIKMALAYA
}

\author{
H. Yus Darusmanl1), H. Mumu' ${ }^{2}$, Ahmad Hamdan ${ }^{3)}$ \\ ${ }^{1,2}$ Jurusan Pendidikan Luar Sekolah Fakultas Keguruan dan Ilmu Pendidikan Universitas Siliwangi \\ yus.darusman@gmail.com²,
}

\begin{abstract}
ABSTRAK
Tujuan umum pelaksanaan pengabdian pada masyarakat ini adalah untuk meningkatkan kemampuan dalam manajemen berwirausaha para pengusaha dan karyawan daur ulang limbah agar dapat meningkatkan kualitas wirausaha yang dijalankan. Permasalahan yang ditemui pada masayrakat yaitu kurangnya pengetahuan para pengusaha danpekerja tentang manajemen wirausaha, sehingga kondisi ekonomi yang terjadi pada masyarakat tidak berkembang signifikan. Masyarakat juga perlu adanya peningkatan keterampilan yang berkelanjutan agar dapat lebih berdaya saing melihat pangsa pasar dan pengembangan produk yang dimilikinya. Program pengabdian ini bermitra dengan LKP Yuwita dan pemerintah serta pengusaha setempat dalam rangka mendorong masyarakatnya menjadi daerah yang memiliki ciri khasnya tersendiri. Tim pelaksana dalam kegiatan pengabdian pada masyarakat ini berasal dari program studi pendidikan luar sekolah universitas Siliwangi sebanyak tiga orang yang merupakan bagian dari kepakaran Pendidikan Kemasyarakatan Nonformal dan Informal sebagai narasumber.
\end{abstract}

Kata kunci : Pelatihan, Wirausaha, Manajemen, Pendidikan Kecakapan Hidup.

\begin{abstract}
The general purpose of implementing community service is to improve the ability in entrepreneurial management of entrepreneurs and employees to recycle waste to improve the quality of the entrepreneurship that they run. Problems encountered in the community are a lack of knowledge of entrepreneurs and workers about entrepreneurial management so that the economic conditions that occur in society do not develop significantly. The community also needs a continuous improvement of skills to be more competitive given market share and product development. This service program is partnering with LKP Yuwita and the government and local entrepreneurs to encourage their communities to become regions that have their characteristics. The implementing team in the community service activities came from the Siliwangi University School of Education study program as many as three people who are part of the field of expertise in Non-formal and Informal Community Education as resource persons.

Keywords: Training, Entrepreneurship, Management, Life Skills Education.
\end{abstract}

\section{A. PENDAHULUAN}

Persoalan kemiskinan merupakan permasalahan yang seakan-akan tidak ada habisnya di negeri ini. Sejak sebelum Indonesia merdeka sampai pada saat Indonesia sudah merdeka, bahkan sampai pada saat era globalisasi permsalahan kemiskinan masih menghantui masyarakat. Pemerintah dengan segala upaya dan kebijakannya dalam mengurangi permasalahan kemiskinan di masyarakat, akan tetapi masih belum ada perubahan yang signifikan. Menurut Syawie dalam Nainggolan (2012:1) kemiskinan merupakan kondisi saat seseorang atau sekelompok orang tak mampu memenuhi hakhak dasarnya untuk mempertahankan dan mengembangkan kehidupan yang bermartabat. Kemiskinan merupakan persoalan yang sangat kompleks dan kronis, 
sehingga menanggulangi nya diperlukan solusi yang terintegrasi dari berbagai komponen yang sifatnya berkelanjutan.

Melalui program tersebut dunia usaha semakin berkembang, kemunculan para wirausahawan baik skala kecil maupun besar merupakan fenomena yang biasa. Fenomena ini mengakibatkan tingkat persaingan antara pelaku kegiatan usaha menjadi semakin ketat. Persaingan dalam dunia usaha di satu sisi dapat berpangaruh positif yaitu dorongan untuk selalu meningkatkan mutu produk yang dihasilkan, akan tetapi persaingan juga dapat menimbulkan dampat yang negative diantaranya produk yang mereka buat akan tergusur di pasaran apabila gagal dalam meningkatkan mutu dan kualitas produknya.

Drucker (1994: 27) mengatakan kewirausahaan adalah suatu kemampuan untuk menciptakan sesuatu yang baru dan berbeda (ability to create the new and diferent). Salah satunya dengan melirik pada pemanfaatan bahan limbah kain yang sudah tidak dibutuhkan lagi, dan kebanyakan orang beranggapan bahwa sisa kain (majun) sudah menjadi sampah yang tidak dapat digunakan.

Pemanfaatan limbah kain merupakan suatu inovasi produk rumah tangga yang dapat diolah dan menciptakan peluang usaha dalam meningkatkan perekonomian masyarakat yang produktif, seperti yang diungkapkan oleh Howard Kingsley dalam Sudjana (2004; 4) bahwa pada dasarnya bentuk dari hasil belajar dapat di bagi menjadi tiga macam, yaitu 1) keterampilan dan kebiasaan; 2) pengetahuan dan pengertian; 3) sikap dan cita-cita. Pendidikan luar sekolah, memiliki kajian diantaranya adalah pemberdayaan masyarakat. Pemberdayaan masyarakat memiliki peran yang sangat sentral bagi masyarakat untuk menjadi leih berdaya, baik itu dalam hal pendidikan, ekonomi, kesehatan dan lainnya.

Pendidikan dan pelatihan banyak kita dengan dalam dunia kerja, organisasi, lembaga atau bahkan instansi. Hal ini diasumsukan bahwa pendidikan dan pelatihan sangat penting perannya bagi individu untuk lebih meningkatkan dan menguasai keterampilan agar dapat bertahan dan mengembangkan potensi dirinya. Pada dasarnya pendidikan dan pelatihan sering dilakukan sebagai upaya untuk meningkatkan kinerja para tenaga kerja untuk menyesuaikan dengan kondisi dan perkembangan kebutuhan masyarakat.

Berdasarkan pada kondisi obyektif yang ada, pelatihan manajemen wirausaha daur ulang limbah kain di Kelurahan Sukamanah Kecamatan Cipedes Kota Tasikmalaya pada 
dasarnya bertujuan untuk memberdayakan masyarakat dalam melihat peluang usaha dan memanej kegiatan usaha yang dijalankan tetap bertahan dan berkelanjutan demi meningkatkan taraf hidupnya. Manajemen kewirausahaan berkaitan dengan keseluruhan kekuatan usaha yang dijalankan yang menjamin bahwasannya usahanya betul-betul akan terus eksis dan bertahan di tengah persaingan pasar yang semakin ketat. Seorang wirausahawan harus memiliki 4 kompetensi diantaranya yaitu: 1) focus pada pangsa pasar, bukan pada teknologi; 2) buat ramalan pembiayaan yang terjadi pada usahanya agar kebutuhan usaha terpenuhi; 3) bangun tim manajemen usahanya dengan baik; 4) berbagi peran tertentu, terutama bagi penemu usahanya.

Upaya yang dilakukan yaitu melalui pengaturan manajemen wirausaha yang baik dalam mendaur ulang, melihat pangsa pasar, manajemen keuangan dan manajemen wirusaha lainnya sehingga menghasilkan produk yang bernilai dan berkelanjutan. Dalam pengadian ini kami sebagai tim Jurusan Pendidikan Luar Sekolah berusaha menjembatani permasalahan yang ada pada kondisi saat ini di lapangan. Dengan adanya program pelatihan manajemen wirausaha daur ulang limbah, diharapkan masyarakat yang berwirusaha dalam bidang ini selalu terus dapat menciptakan peluang usaha dan melihat pangsa pasar serta memanej usaha nya dengan baik dan mampu lebih berdaya dan bersaing dengan lainnya.

\section{B. LANDASAN TEORI}

Manajemen berasal dari Bahasa latin, yaitu manus yang berarti tangan dan angere yang berarti melakukan. Jika digabungkan menjadi kata kerja manager yang artinya menangani. Managere diterjemahkan dalam Bahasa inggris dalam bentuk kata kerja to manage, dengan kata benda management dan manager untuk orang yang melakukan kegiatan manajemen. Dalam Bahasa Indonesia management diterjemahkan menjadi manajemen atau pengelolaan (Usman, 2010:5).

Manajemen menurut Henry (1969: 10) management is the coordination of all resources through the processes of planning, organizing, directing, and controlling in order to attain stated objectives. Manajemen merupakan mengkoordinasikan semua sumber daya melalui proses perencanaan, pengorganisasian, penggerakan dan control guna mencapai tujuan secara obyektif.

Terry (2005:1) mengartikan manajemen merupakan proses atau kerangka kerja, yang melibatkan bimbingan atau pengarahan suatu kelompok orang-orang kearah 
tujuan-tujuan organisasional atau maksud-maksud yang nyata. Hal tersebut meliputi pengetahuan tentang apa yang harus dilakukan, menetapkan cara bagaimana melakukannya, memahami bagaimana mereka harus melakukannya dan mengukur efektivitas dari usaha-usaha yang telah dilakukan.

Pendekatan manajemen bertujuan untuk menganalisis proses, membangun kerangka konseptual kerja, mengidentifikasi prinsip-prinsip yang mendasarinya. Manajemen bersifat universal yang berkenaan dengan adanya jenis lembaga, berbagai posisi dalam lembaga atau pengalaman pada lingkungan yang beragam luasnya antara berbagai persoalan kehidupan terutama dalam hal ini adalah dalam bidang wirausaha.

Manajemen berisikan unsur struktur organisasi yang tersusun, terarah sesuai dengan tujuan dan sasaran, dilakukan hasil usaha para anggotanya, menggunakan system dan prosedur yang jelas.

Menurut Terry $(2010$; 9) fungsi manajemen dapat dibagi menjadi empat bagian, yaitu planning (perencanaan), organizing (pengorganisasian), actuating (pelaksanaan), dan controlling (pengawasan).

\section{Planning}

Perencanaan adalah penetapan pekerjaan yang harus dilaksanakan oleh kelompok untuk mencapai tujuan yang dirancang. Planning mencakup kegiatan pengambilan keputusan karena termasuk dalam pemilihan alternatif-alternatif keputusan.

\section{Organizing}

Organizing berasal dari kata organon dalam Bahasa Yunani yang berarti alat, yaitu proses pengelompokan kegiatan-kegiatan untuk mencapai tujuan-tujuan dan penugasan setiap kelompok kepada seorang pimpinan. Pengorganisasian dilakukan untuk menghimpun dan mengatur semua sumber-sumber yang diperlukan, termasuk manusia, sehingga pekerjaan yang dikehendaki dapat dilaksanakan sesuai dengan yang sudah direncanakan.

\section{Actuating}

Pelaksanaan merupakan usaha menggerakan anggota-anggota kelompok sedemikian rupa, hingga mereka berkeinginan dan berusaha untuk mencapai tujuan yang telah direncanakan bersama.

\section{Controlling}


Controlling atau pengawasan adalah penemuan dan penerapan cara dan alat untuk menjamin bahwa rencana telah dilaksanakan sesuai dengan rencana yang telah ditetapkan.

Alat-alat dalam manajemen organisasi menurut Abdulsyani (1987: 18) dapat dirumuskan dalam 5M, yaitu:

1. Man

Tenaga kerja manusia sebagai sarana utama untuk mencapai tujuan yang telah ditentukan oleh individu-individu. Berbagai kegiatan-kegiatan yang dapat diperbuat dalam mencapai tujuan seperti yang dapat ditinjau dari sudut pandang proses, perencanaan, pengorganisasian, staffing, pengarahan, dan pengawasan atau dapat pula kita tinjau dari sudut bidang seperti penjualan, produksi, keuangan dan personalia.

\section{Money}

Uang yang diperlukan untuk mencapai tujuan. Uang sebagai sarana manajemen harus digunakan sedemikian rupa agar tujuan yang diinginkan tercapai. Kegiatan atau hambatan proses manajemen sedikit banyak dipengaruhi oleh pengelolaan keuangan.

\section{Methods}

Cara atau system untuk mencapai tujuan. Untuk melakukan kegiatan agar berhasil, manusia dihadapkan pada berbagai alternative metode cara menjalankan pekerjaan sehingga cara yang dilakukannya dapat menjadi sarana atau alat manajemen untuk mencapai tujuan.

\section{Materials}

Bahan-bahan yang diperlukan dalam kegiatan. Dalam proses pelaksanaan kegiatan, manusia menggunakan material atau bahan-bahan. Oleh karena itu material dianggap pula sebagai alat atau sarana manajemen untuk mencapai tujuan

\section{Market}

Pasar atau tempat untuk memasarkan hasil produksi. Pasar merupakan salah satu sarana manajemen penting untuk mendapatkan laba/keuntungan agar usaha yang dijalankan dapat berjalan dan berkembang.

Kewirausahaan menurut Hendro (2011: 29) berasalah dari berbagai padanan kata. Kata entrepereneur berasalah dari bahasa Prancis, yaitu entreprende yang berarti petualang, pengambil resiko, kontraktor, pengusaha (orang yang mengusahakan suatu pekerjaan), dan pencipta yang menjual hasil ciptaannya. Esensi dasar dari 
kewirausahaan adalah menciptakan nilai tambah di pasar melalui proses pengkombinasian sumber daya dengan cara-cara baru dan berbeda agar dapat bersaing.

Menurut Drucker (1994, hlm. 27) kewirausahaan adalah suatu kemampuan untuk menciptakan sesuatu yang baru dan berbeda (ability to create the new and different). Wirausaha adalah kemampuan yang dimiliki oleh seseorang untuk melihat dan menilai kesempatan - kesempatan bisnis, mengumpulkan sumberdaya-sumberdaya yang dibutuhkan untuk mengambil tindakan yang tepat dan mengambil keuntungan dalam rangka meraih sukses.

Wirausahawan adalah seorang innovator, sebagai individu yang mempunyai naluri untuk melihat peluang-peluang, mempunyai semangat, kemampuan dan pikiran untuk menaklukan cara berpikir lamban dan malas. Kewirausahaan merupakan kegiatan yang menuntut karakteristik tertentu dari pelakunya dan kegiatan untuk melakukan usaha tersebut. Oleh karena itu Clelland seperti dikutip Suryana (2001) dalam Kamil (2010, hlm. 122) mengemukakan bahwa karakteristik wirausaha adalah:

1. Keterampilan mengambil keputusan dan mengambil risiko yang moderat, dan bukan atas dasar kebutuhan belaka;

2. Beraifat energik, khususnya dalam bentuk berbagai kegiatan inovatif;

3. Tanggung jawab individual;

4. Mengetahuai hasil-hasil dari berbagai keputusan yang diambilnya dengan tolok ukur satuan uang sebagai indikator keberhasilan;

5. Mampu mengantisipasi berbagai kemungkinan di masa datang;

6. Memiliki kemampuan berorganisasi, yaitu seseorang wirausaha memiliki kemampuan keterampilan, kepemimpinan, dan manajerial.

Manajemen kewirausahaan merupakan pendayagunaan potensi ekonomis secara kreatif, inovatif dan dengan keberanian menghadapi resiko untuk mendapatkan laba yang berguna mensukseskan program atau organisasi. Manajemen dalam kegiatan wirausaha dibutuhkan untuk memperlancar proses wirausaha dan mendapatkan keuntungan yang sebesar-besarnya.

Adapun fungsi-fungsi yang terdapat dalam manajemen kewirausahaan adalah sebagai berikut:

1. Perencanaan (Planning)

Perencanaan adalah proses menentukan arah yang akan ditempuh dan kegiatankegiatan yang diperlukan untuk mencapai tujuan yang telah ditetapkan. Dalam proses 
ini ditentukan tentang apa yang harus dilakukan, kapan dikerjakan/dimulai, bagaimana melakukannya, dengan cara apa hal tersebut dilaksanakan, dan siapa yang akan melakukan pekerjaan tersebut. Proses tersebut itulah yang pada akhirnya akan menghasilkan suatu rencana.

\section{Pengorganisasian (Organizing)}

Pengorganisasian adalah proses pengelompokan berbagai kegiatan atau pekerjaan dalam unit-unit. Tujuannya adalah supaya tertata dengan jelas antara tugas, wewenang, dan tanggung jawab serta hubungan kerja dengan sebaik mungkin dalam bidangnya masing-masing. Hasil dari pengorganisasian ini adalah terbentuknya struktur organisasi sesuai dengan rencana yang telah disusun.

\section{Pelaksanaan (Actuating)}

Menggerakkan atau melaksanakan adalah proses untuk menjalankan kegiatan atau pekerjaan dalam organisasi. Dalam menjalankan organisasi para pemimpin atau manajer harus menggerakkan bawahannya (para karyawan) untuk mengerjakan pekerjaan yang telah ditentukan dengan cara memimpin, memberi perintah, memberi petunjuk dan memotivasi, pelaksanaan pekerjaan dilakukan dengan berpedoman pada rencana yang telah disusun.

\section{Pengawasan (Controlling)}

Controlling (pengawasan) adalah proses untuk mengukur dan menilai pelaksanaan tugas apakah telah sesuai dengan rencana. Jika dalam proses tersebut terjadi penyimpangan, maka akan segera dikendalikan sesuai dengan rencana yang disusun. Dengan adanya pengendalian diharapkan tujuan dapat dicapai sesuai dengan target yang telah ditetapkan. Dalam kegiatan ini juga dilaporkan factor-faktor pendukung dan penghambat kerja, sehingga memudahkan usaha perbaikan. Jadi, pengawasan ini dilihat dari segi input, proses, output bahkan outcomenya telah sesuai dengan tujuan yang ditetapkan atau belum sesuai tujuan yang ditetapkan.

\section{Penilaian (evaluating)}

Pengevaluasian merupakan fungsi lanjutan dari pengawasan. Evaluasi artinya menilai kegiatan untuk menemukan indikator yang menyebabkan sukses atau gagalnya pencapaian tujuan, sehingga dapat dijadikan bahan kajian berikutnya. Dalam mengkaji masalah yang dihadapi, rumuskan solusi alternatif yang dapat memperbaiki kelemahankelemahan yang ada dan meningkatkan kualitas keberhasilan di masa yang akan datang. 
Evaluasi sebagai fungsi manajemen merupakan aktifitas untuk meneliti dan mengetahui pelaksanaan yang telah dilakukan dalam proses keseluruhan organisasi mencapai hasil sesuai dengan rencana atau program yang telah ditetapkan dalam rangka pencapaian tujuan. Dengan mengetahui kesalahan-kesalahan atau kekurangan-kekurangan, perbaikan dan pencarian solusi yang tepat dapat ditemukan dengan mudah.

\section{Motivasi (Motivating)}

Motivasi berasal dari bahasa Latin "movere" yang berarti "dorongan" atau "daya penggerak". Motivasi merupakan suatu kemampuan seseorang untuk memberikan kegairahan, kegiatan, pengertian, sehingga orang lain mau mendukung dan bekerja secara suka rela untuk mencapai tujuan organisasi sesuai dengan tugas yang dibebankan kepadanya. Motivasi dapat juga diartikan sebagai keadaan kejiwaan dan sikap mental manusia yang memberikan energi, mendorong kegiatan atau moves dan mengarah atau menyalurkan perilaku ke arah mencapai kebutuhan yang memberi kepuasan atau mengurangi ketidakseimbangan.

\section{Pembaruan (Innovating)}

Pembaruan atau inovasi adalah suatu proses sistematis dalam menerapkan pengetahuan, sarana, sumber daya yang diperlukan untuk memengaruhi perubahan pada orang yang akan terkena dampak dari proses tersebut. Inovasi merupakan jenis perubahan khusus, berbeda dengan "change" yang berarti membuat sesuatu yang berbeda. Inovasi adalah gagasan baru yang diaplikasikan untuk memulai atau memperbaiki produk, proses, atau jasa.

\section{METODOLOGI}

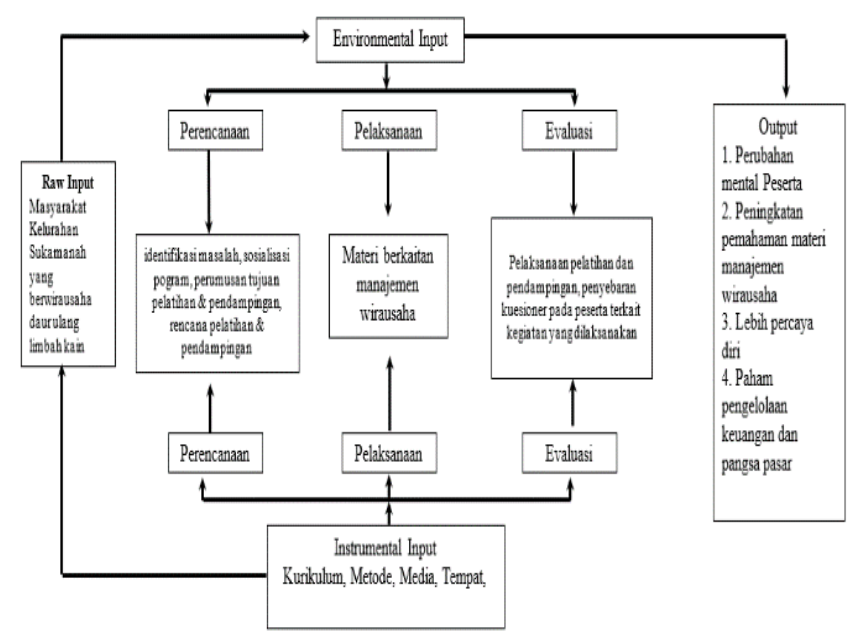

Gambar 1 Desain Pelaksanaan Pelatihan Manajemen Wirausaha Daur Ulang Limbah Kain di Kampung Leuwihalang Kelurahan Sukamanah Kecamatan Cipedes Kota Tasikmalaya 
Sasaran pelaksanaan Pengabdian ini adalah para pengusaha dan pekerja pengolahan limbah kain yang dibuat menjadi celana dalam anak-anak yang bertempat di Kampung Leuwihalang Kelurahan Sukamanah Kecamatan Cipedes. Proses pelatihan pda pengabdian dilaksanakan dengan menerapkan dua metode yaitu Pelatihan dan Pendampingan dalam meningkatkan kompetensi manajemen di bidang wirausaha.

Prosedur kerja dalam mendukung realisasi metode yang ditawarkan adalah:

1. Observasi lapangan dan sosialisai guna mendata calon peserta (pengusaha dan pekerja pengolahan limbah kain)

2. Membuat dan menyediakan materi yang dibutuhkan dalam pembelajaran

3. Mengadakan pelatihan sesuai dengan jadwal yang telah ditentukan bersama

\section{HASIL DAN PEMBAHASAN}

Kegiatan pelatihan dan pendampingan ini dilaksanakan dari mulai tanggal 25 - 30 Agustus 2018. Pada pelaksanaannya, pencapaian kegiatan yang dilaksanakan berada pada tahap pelatihan mengenai konsep dasar manajemen dan motivasi wirausaha. Materi yang diberikan memiliki tujuan untuk mengembangkan pengetahuan dan pengalaman tentang wirausaha yang lebih baik dan professional.

Materi kegiatan pelatihan dan pendampingan pelatihan manajemen wirausaha daur ulang limbah kain adalah sebagai berikut:

1. Motivasi wirausaha ( $1 \times 45$ menit)

2. Manajemen wirausaha ( $2 \times 45$ menit)

Peserta pelatihan pada program ini adalah para pengusaha dan pekerja serta bekerjasama dengan LKP Yuwita dan FK PKBM kota Tasikmalaya, peserta yang mengikuti pelatihan ini 30 orang.

Sarana dan prasarana yang diperlukan dalam kegiatan ini adalah sebagai berikut notebook, projector, HVS, ATK.

Kegiatan pelatihan dilaksanakan pada pukul 10.00 - 15.00 WIB yang bertempat di rumah salah satu pengusaha pengolahan limbah kain. Pelaksanaan pengabdian sesi kedua merupakan tindak lanjut dari pelatihan yaitu pendampingan sebagai pendalaman materi. Materi yang diberikan pada sesi kedua ini yaitu:

1. Pengelolaan keuangan ( $2 \times 45$ menit)

2. Manajemen pemasaran ( $2 \times 45$ menit)

3. Pendampingan ( $4 \times 45$ menit) 


\section{E. KESIMPULAN}

Berdasarkan hasil pelaksanaan kegiatan pengabdian pada masyarakat dengan tema Pelatihan Manajemen Wirausaha Pengolahan Limbah Kain yang bekerjasama dengan LKP Yuwita dan Forum PKBM Kota Tasikmalaya, para pengusaha dan pekerja industri rumahan pengolahan limbah kain perlu diberikan treatment tentang manajemen wirausaha yang baik dan benar, sehingga mereka dapat mengatur kegiatan usahanya sesuai dengan pola manajemen yang ada dan dapat meningkatkan profesionalitas serta peningkatan usaha yang lebih baik. Berdasarkan kegiatan Pengabdian yang sudah dilaksanakan, terdapat beberapa hal yang menjadi saran atau rekomendasi baik untuk pengembangan keilmuan jurusan Pendidikan Masyarakat, pemangku kebijakan, dan para pengusaha serta pekerja pengolahan limbah kain, yakni sebagai berikut: bagi pengembangan keilmuan pendidikan masyarakat dalam rangka meningkatkan kompetensi lulusan maka harus diberikan pengetahuan dan keterampilan tentang pemberdayaan masyarakat dan manajemen program serta pendalaman kajian tentang kewirausahaan agar dapat menyelaraskan program pemberdayaan, manajemen program dan kewirausahaan sebagai salah satu kajian yang saling terkait. Saran atau rekomendasi bagi para pemangku kebijakan, yaitu agar para penguaha yang memiliki industri rumahan diberikan pelatihan agar dapat mengembangkan usahanya dengan baik dan lebih terarah pada usaha yang lebih professional dan dapat meningkatkan kapasitas usahanya. Saran atau rekomendasi bagi pengusaha ataupun pekerja pengolahan limbah kain yaitu agar terus mau membuka wawasan, melihat pangsa pasar dan menggunakan system manajemen usaha yang lebih baik agar usaha dan pekerjaan yang dijalani lebih professional.

\section{F. DAFTAR PUSTAKA}

Abdulsyani. (1987). Manajemen Organisasi. Jakarta: Bina Aksara.

BPS. (2017). Statistik Daerah Provinsi Jawa Barat 2017. Provinsi Jawa Barat.

Drucker, P. F. (1994). Innovation and Entrepreneurship, Practice and Principles. Jakarta: Gelora Aksara Pratama Erlangga.

Hendro. (2011). Dasar-dasar Kewirausahaan. Jakarta: Erlangga. 
Kementrian Pendidikan dan Kebudayaan. (2017). APK dan APM PAUD, SD, SMP, dan SM (Termasuk Madrasah dan Sederajat). Jakarta: Pusat Data Statistik Pendidikan dan Kebudayaan.

Nainggolan, T. (2012). Program Keluarga Harapan di Indonesia: Dampak Pada Rumah Tangga Sangat Miskin di Tujuh Provinsi. Jakarta: P3KS Press.

Sisk, Henry, L. (1969). Principle of Management. Brighton England: South Western Publishing Company.

Sudjana, D. (2004). Wawasan Sejarah Perkembangan Falsafah dan Teori Pendukung Asas. Bandung: Falah Production.

Terry, G. (2005). Dasar-dasar Manajemen. Jakarta: Bumi Aksara.

Terry, G dan Leslie W. Rue (2010). Dasar-dasar Manajemen. Jakarta: Bumi Aksara.

Usman, H. (2010). Manajemen Teori, Praktik, dan Riset Pendidikan. Jakarta: Bumi Aksara. 